\title{
Information Literacy Skills for Preservice Teachers: \\ Do They Transfer to K-12 Classrooms?
}

By Marcia Stockham and Heather Collins

\begin{abstract}
This study surveyed current education majors $(n=70)$ in two Kansas universities to gain a perspective on their understanding of Information Literacy (IL) concepts and skills, and to learn whether they anticipated teaching such concepts to their future K-12 students. School media specialists in the state were also surveyed $(n=85)$ and asked to share their observations of teachers new to the profession as to their understanding and practice of IL. Results indicate many education students were not familiar with IL concept terminology and at least some new teachers in the state do not have a clear understanding or priority for teaching such skills in K-12 classrooms.
\end{abstract}

\section{Introduction}

Academic education librarians working with future teachers perform multi-faceted work. One critical role includes teaching the Association of College and Research Libraries' (ACRL) Information Literacy Competency Standards within the discipline of education (ACRL, 2000). More recently, Information Literacy Standards for Teacher Education have been formulated and endorsed by the ACRL's Education and Behavioral Sciences Division (EBSS Instruction for Educators Committee, 2011). Librarians frequently extol the benefits of information literacy (IL) to empower students in their future professional endeavors. Academic education librarians teach IL skills to future teachers, and thus share an increased responsibility for promoting IL as part of the learning cycle: librarians to teachers to students. Since teachers cannot teach what they do not know, it is necessary for teacher education programs and libraries to collaborate in meeting ACRL student learning outcomes for information literacy. At Kansas State University and at Washburn University, librarians bring instruction to targeted education courses, strategically weaving IL skills into various points in the curriculum. This study focused on the extent to which preservice teachers absorb and then embed these concepts into future K-12 learning experiences, thus transmitting information literacy.

Collaborations between academic education departments and education libraries/librarians can set an important example for student teachers moving into professional practice. The education librarian has an opportunity to model not only the use of information seeking skills, but also the collaboration potential for teachers and school librarians. If education libraries and librarians give preservice teachers tools that can enhance their lifelong learning habits, perhaps, in turn, those education students can impact their future students not just sporadically, but as a matter of practice throughout a student's educational career. Academic institutions will then begin to see students entering their doors with even greater IL levels.

Washburn University Libraries' mission includes the vision to “ ... guide teaching, learning and research in the transformation of our community..." (Washburn University Libraries mission statement, 2011). Likewise, Kansas State University Libraries' mission and vision statement includes terms which highlight the comprehensive change affected upon students as they matriculate. "We guide our community in its quest for intellectual discovery and lifelong learning" (Kansas State University Libraries mission statement, 2011). In this study, perspective was sought to understand the impact that education librarians and libraries have on lifelong learning and student transformation.

When evaluating this cycle of teachers, students, and librarians, it is important to acknowledge a potential disconnect between skills needed for a task-based event and the disposition-changing mastery of knowledge. Transformative change would be evidenced in lifelong habits, not in short-term task completion. The incorporation of information literate practices in task-based skills such as completing projects, preparing lesson plans, or creating a teaching unit as a college or university student, might or might not be replicated in 
future professional practice. Common authentic programmatic or university-wide assessment tools such as the Educational Testing Service iSkills (ETS, 2011) only reflect current proficiencies, but what happens when education students leave college and enter professional practice? Are student teachers internalizing IL skills for future use and will they be able to impart those skills in their future classrooms?

To help answer those questions, this study was designed with three objectives. First, the study sought data on whether school media specialists had observed new professional teachers in their schools integrate information literacy concepts into their classrooms. Second, it sought to discover whether undergraduate education students are familiar with the concepts of IL and are prepared to incorporate IL concepts into their future teaching. Third, distribution of the survey to participants served as a tool to identify librarians as educational partners and impart knowledge about the K-12 information literacy standards, Information Power (American Association of School Librarians \& Association for Educational Communications and Technology, 1998) as well as IL models such as the Big Six (Eisenberg, 2001) and the Handy Five (Blume, Fox, Lakin, Losey, \& Stover, 2007).

\section{Literature Review}

Academic librarians realize that not all college students understand IL concepts and this observation is supported in the literature. The Chronicle of Higher Education reports on an Educational Testing Service (ETS) study that found "college students and high-school students preparing to enter college are sorely lacking in the skills needed to retrieve, analyze, and communicate information available online" (Foster, 2006). ETS representatives stressed that the findings were "neither authoritative nor thorough" but did indicate that students can use more training in information literacy. Another study attempting to gauge undergraduate perceptions of information literacy determined that the study group viewed information seeking as focused on product outcome rather than the underlying knowledge base and skills. This group also assumed that everyone has these skills, partially as a result of growing up with computers, and that information seeking skills can be self-taught. They reported having very little information literacy training and the term itself did not resonate with them (Gross \& Latham, 2009). Clearly, there is work to be done in order to help many students develop these important skills.

One possible solution for bridging the gap between understanding the need for learning such skills and the impact on information seeking is to ensure that classroom teachers incorporate basic IL concepts starting with young school children and continuing through secondary school. While school media specialists work diligently with these students, many do not have the time or opportunity to integrate skill practice into daily lessons and assignments. Classroom teachers, on the other hand, might have this opportunity, but it doesn't seem they are fully prepared for this role during their undergraduate years.

Despite the lack of priority these skills receive in practice, the need for teachers to develop IL skills is recognized and emphasized internationally. In a white paper prepared for UNESCO, (Moore, 2002) recommendations to Departments of Education include the following: a) ensure preservice teachers experience information literacy as an aid to them as learners, instructional designers and responsive facilitators of learning ensure newly qualified teachers are competent to develop information literacy experiences for their students; b) ensure professional development for in-service teachers involves personal experience in learning through information literacy and information computer technology (ICT); c) ensure education for school and/or teacher-librarianship maintains a focus on consistent, coherent information literacy development.

Several examples in library literature describe IL initiatives with preservice teachers (Asselin \& Lee, 2002; Floyd, Colvin, \& Dodur, 2008). Earp describes a successful grant project that reached a large number of education students through IL classes that evolved into workshops and finally, into online modules and illustrated a true collaboration with education faculty (Earp, 2009). A Canadian study found that outgoing 
teacher candidates did not understand the concept of information literacy and were not prepared to teach IL skills when leaving the program. These findings led to the development of a program aimed to help preservice teachers expand these skills (Laverty \& Reed, 2006). Such examples illustrate the recognized need for preservice education students to learn IL skills, with the assumption that those skills might be carried into the classroom as the students become professional teachers. In addition to targeting preservice teachers, one article described an example of a graduate-level instruction for teacher practitioners to help them master skills and build tools to improve the IL skills of their students (Bushong \& Buff, 2008). However, there does not seem to be longitudinal or empirical evidence available in the literature documenting evidence that these skills transfer to the classroom.

Many states are currently struggling with economic factors unfavorable to public schools. While it is documented that school librarians provide value to students (Latham \& Gross, 2008) (Dow, 2010), many districts are being forced to cut library positions. In such an economic and political climate, it is imperative that classroom teachers be able to integrate IL skills into their teaching, or at the very least, to understand the importance of collaborating with school librarians whenever possible. In Kansas, a recent study looked at the effects of state-licensed school library media specialists on student achievement (Dow, 2011), but there do not seem to be any reports attempting to assess the contribution of classroom teachers to help their students learn IL skills.

\section{Methods}

Two separate surveys were developed by the authors - one for school media specialists throughout the state and one for current education students at the authors' universities. Survey questions were in a multiplechoice format and were shared with a college-level instructor, a middle-school librarian, and library colleagues to test for clarity and interpretation. All questions allowed for an "other" or free response in addition to the given choices. The introductory message and survey questions appear in Appendix A.

Permission was received from the Institutional Review Board (IRB) at each institution and the survey was generated through survey software available at Kansas State University. Two methods to access the survey were utilized: an e-mail explaining the project with a link to the survey was sent to the listserv of the Kansas Association of School Librarians (KASL); e-mail addresses of individual students were entered into the system so that they received the explanatory message and a unique link to the survey. The pool of students was obtained through faculty at each university. At Kansas State University, faculty circulated a list for students to indicate their e-mail address if they were willing to participate in the project. At Washburn, inperson classes were approached by either the librarian or the instructor and volunteers sought. Volunteers from online classes were approached by the instructor. Eligible students visiting the library were also invited to participate. Students had junior or senior status.

Students from both institutions $(\mathrm{m} 1=127)$ were identified as potential subjects, as well as members from the Kansas Association of School Librarians KASL-L listserv (m2 465$)$. While not all School Media Specialists in the state (approximately 1100) belong to the listserv, this organization is the largest professional collective, and therefore the most efficient way to reach as many respondents as possible for purposes of this study.

Separate identical surveys were sent to each group of students so that results could be analyzed both for individual classes and as a composite. Surveys were available to respondents for 9 days (students) and 11 days (media specialists). Near the end of the survey period, reminders were sent through the listserv and automatically generated for individual students through the survey system as a way to increase the responses. 
At the end of the survey period, numeric results were compiled and open-ended question responses were categorized. A varying number of respondents chose not to answer individual questions, so the responses for each question did not reflect a constant number. Percentages were rounded to the nearest whole number, and the sums do not always equal 100 percent, depending on whether respondents answered all questions. The individual class results were used by the authors as a way to assess current knowledge and identify areas where work with students could be enhanced at respective institutions. Composite results were used for this paper in order to provide a larger sampling.

\section{Results}

\section{School Media Specialists/Librarians}

Of the subscribers to the listserv $(\mathrm{m} 2 \approx 465), 126$ individuals started the survey and $(\mathrm{n} 2=85)$ completed it for a response rate of $18 \%$. Two related questions on the survey were designed to assess the school librarians' perceptions of new teachers' familiarity with IL skills and concepts. See Table 1 for summary of results. Only $16 \%$ of the respondents indicated that they thought new graduates in their schools demonstrated a clear understanding of IL skills and concepts and over 50\% indicated that they did not think the new graduates themselves had a solid understanding of IL skills and concepts. Thirty-three percent of the respondents indicated they didn't know or gave no response. While many comments stated that it was hard to generalize, some comments gave examples as to why the answers were not more positive:

- Many new teachers believe the ability to "Google" constitutes mastery of IL and ICT skills

- Teachers confuse IL with basic technology skills

- It seems there is no overall emphasis on "teaching the teachers" these skills and concepts

- The emphasis on testing keeps teachers from giving sufficient time to IL

- Some new teachers are learning from veteran teachers living in the older paradigm that libraries are for checking out books

- Some new teachers have good skills, but don't seem to be transferring them to their students.

The remainder of the questions to the media specialists concerned observed behavior regarding various aspects of IL (See Table 1). The question asking how they may have observed a demonstration in the classroom of awareness of these skills elicited some negative comments such as: most teachers stay in their rooms and use internet and PowerPoint; teachers bring classes to the media center because they are "required" to; some will use the library media specialist, but others have to be reminded.

When asked to describe the level of collaboration or relationships the media specialists had with new teachers, $40 \%$ of the responses were either "They are aware of concepts and skills, but I have not seen them incorporate them into routine work" or "I find that I have needed to educate/inform them of methods and importance for teaching these skills." "They collaborate frequently with me to teach information literacy skills" and "They prefer to teach these skills without me" each accounted for $8 \%$ of responses with "They mostly expect me to teach these skills" garnering $15 \%$ of responses. The remainder either marked "Other" or did not respond. A variety of comments accompanied this range of responses:

- Sometimes library time serves as planning time so our collaboration time is quite limited

- If state standards are not tested, the school district does not emphasize those skills

- Some teachers don't understand the concept of collaboration

- Most new teachers enjoy accessing web pages but few understand researching with databases

- New teachers are so focused on "the" unit they are responsible for that they have trouble collaborating with me

- Some new teachers have no idea how a librarian can work with them on assignments. 
Table 1. Media Specialists Responses Regarding New Teachers' IL Presence/Use in the Classroom

\begin{tabular}{|c|c|}
\hline $\begin{array}{l}\text { Q. In your opinion, what level of understanding of } \\
\text { information literacy concepts and skills do most new } \\
\text { graduates demonstrate? }\end{array}$ & $\begin{array}{l}\text { Percentage } \\
\text { of } \\
\text { responses }\end{array}$ \\
\hline Demonstrate clear understanding & 16 \\
\hline Demonstrate low understanding & 39 \\
\hline Have no awareness of concepts & 12 \\
\hline I don't know/other/no response & 33 \\
\hline \multicolumn{2}{|l|}{$\begin{array}{l}\text { Q. In your opinion, do new education graduates have a solid } \\
\text { understanding of information literacy skills and concepts? }\end{array}$} \\
\hline Yes & 20 \\
\hline No & 53 \\
\hline No response & 27 \\
\hline \multicolumn{2}{|l|}{$\begin{array}{l}\text { Q. Have you observed new graduates demonstrate an } \\
\text { awareness of these skills by doing any of the following? }\end{array}$} \\
\hline Modeling skills to students & 14 \\
\hline Talking about skills to students & 15 \\
\hline Integrating skills into assignments/rubrics & 26 \\
\hline $\begin{array}{l}\text { Bringing students to media center with expectations of } \\
\text { learning skills }\end{array}$ & 28 \\
\hline I don't know/other/no response & 52 \\
\hline \multicolumn{2}{|l|}{$\begin{array}{l}\text { Q. In your opinion, do these new graduates know where and } \\
\text { how to find needed reference or professional materials? }\end{array}$} \\
\hline Yes, have a good idea & 8 \\
\hline Have some idea & 47 \\
\hline No, don't seem to know where to find appropriate materials & 14 \\
\hline I don't know/other/no response & 31 \\
\hline
\end{tabular}

The final question to the media specialists, "What information literacy concepts or skills do you feel should be stressed more to college education majors?" elicited responses from 45 respondents. The majority of comments fell into these four major categories: specific IL skills, collaboration, evaluation, and exclusive use of the internet (Table 2). 
Table 2. Suggestions from Media Specialists as to What Concepts/Skills Should be Stressed to College Education Majors

\begin{tabular}{|l|l|}
\hline Category of Response & Examples of Responses \\
\hline Specific IL skills & $\begin{array}{l}\text { Stressing plagiarism, proper citation, and copyright rules; the need for } \\
\text { integrated curriculum tying research into every subject; how to use the } \\
\text { library; new teachers have learned many of the pieces but have missed } \\
\text { the bigger picture. }\end{array}$ \\
\hline Collaboration & $\begin{array}{l}\text { School library media specialists should be thought of as teachers, not } \\
\text { support; if information resources are delivered via technology, staff and } \\
\text { administration don't see it as information literacy skills and think it } \\
\text { should be taught in "computer classes". }\end{array}$ \\
\hline Evaluation & $\begin{array}{l}\text { Integrating skills with evaluation; critical thinking skills to evaluate } \\
\text { authority/credibility, especially of web sites. }\end{array}$ \\
\hline $\begin{array}{l}\text { Exclusive use of the } \\
\text { internet }\end{array}$ & $\begin{array}{l}\text { Learning to use more than "google" for everything; utilizing a variety } \\
\text { of formats (print and non-print) in their assignments. }\end{array}$ \\
\hline
\end{tabular}

\section{Education Students}

The survey was distributed to education students $(\mathrm{m} 1=127)$ with a response rate of $55 \%(\mathrm{n} 1=70)$. Four questions were preceded with this statement: "Information Literacy competencies include accessing, evaluating, and using needed information in an appropriate way" to give context to the questions. A summary of results appears in Table 3.

Table 3. Education Student Responses to Survey Statements

\begin{tabular}{|c|c|c|}
\hline Survey Statement & Response & $\begin{array}{l}\text { Percentage of } \\
\text { Responses }\end{array}$ \\
\hline \multirow[t]{3}{*}{$\begin{array}{l}\text { I know how to find the needed information for my } \\
\text { college class papers or projects }\end{array}$} & Frequently & 56 \\
\hline & Occasionally & 41 \\
\hline & Rarely & 3 \\
\hline \multirow[t]{3}{*}{$\begin{array}{l}\text { If I don't know where to look for information, I ask } \\
\text { a librarian or my instructor }\end{array}$} & Frequently & 67 \\
\hline & Occasionally & 24 \\
\hline & Rarely & 9 \\
\hline \multirow[t]{3}{*}{$\begin{array}{l}\text { I carefully evaluate the information I find to } \\
\text { determine whether it is accurate, believable, } \\
\text { appropriate for my use }\end{array}$} & Frequently & 49 \\
\hline & Occasionally & 27 \\
\hline & Rarely & 23 \\
\hline \multirow[t]{2}{*}{$\begin{array}{l}\text { I use the information ethically and know how to } \\
\text { appropriately cite references }\end{array}$} & Frequently & 85 \\
\hline & Occasionally & 15 \\
\hline
\end{tabular}


The fifth question was preceded by this statement: "Information Literacy Competencies for K-12 students (also called Information Power Standards, Handy 5, Big 6, etc.) include concepts such as: knowing how to access, evaluate and use information in order to become independent learners that allow them to become socially responsible." When asked whether the students were familiar with these concepts, only $10 \%$ indicated they were "very familiar." Fifty-one percent indicated they were "somewhat familiar" or had "heard of them", while 39\% indicated this was the first they had heard of them.

Figure 1.

\section{Students' familiarity with IL concepts such as Information Power Standards, Big6, Handy 5}

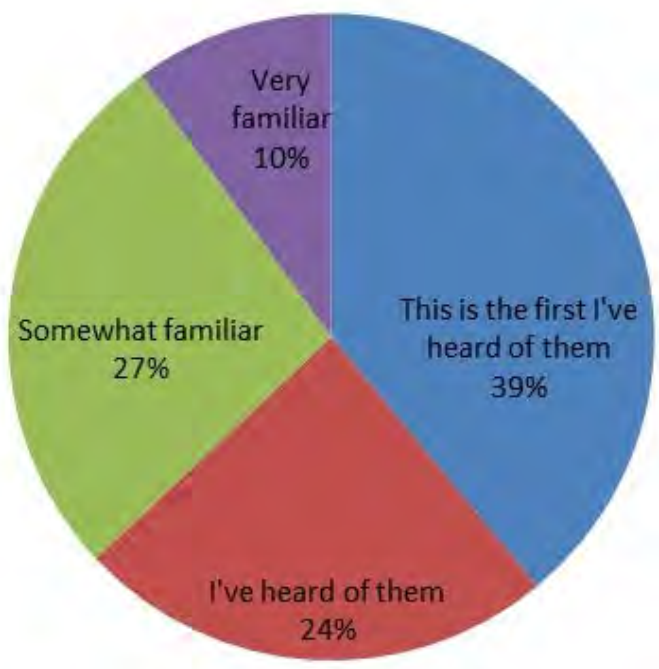

Students were also asked whether they had constructed lesson plans or thematic units that teach any of the skills that had been mentioned in the survey. Seventy-six percent responded with a "no", with most explanations being that they had not actually constructed lesson plans yet, or that they had not known about these concepts. Examples cited by students who indicated they had constructed plans using the concepts include the following: evaluating news story sources and the potential of bias; developing a webquest for a math lesson to work on research skills; a unit on how to use information in social studies; look up and evaluate information on the Boston Tea Party.

When asked to think about their future teaching, $89 \%$ saw teaching IL skills and concepts as a priority or high priority in the classroom. Asked to select which methods they would use, each of the following received at least a $60 \%$ response: modeling IL standards to students; talking about IL standards to students; integrating standards into assignments/rubrics; bringing students to the media center with expectations of learning these skills from the media specialist.

The last question posed to the students was open-ended and asked where they would seek help or resources to teach the concepts. Over $67 \%$ responded with the library, librarian, media specialist or some other iteration of the library. A few mentioned fellow teachers and technology coordinators as well as professional journals. 


\section{Discussion}

Although the sample population was relatively small, the collected data provides valuable information for the academic librarians and education faculty at the participating institutions. Comments from both the students and the media specialists highlight areas for academic librarians to be aware of and to emphasize as they work with future teachers.

It is important to remember that the information collected from the school media specialists was based on their observations, perceptions, and opinions. While the respondents by no means represented all school districts in the state, it was clear that at least some of them feel that new (and veteran) teachers don't always recognize the value of librarians' knowledge and ability to work as partners in teaching IL skills to K-12 students. Promoting such collaboration is certainly something that academic librarians can do as they work with education majors. It should also be noted that no demographics were gathered for the survey, so any differences between school size or grade levels cannot be made at this time. It is recommended that any future studies include such information.

There was agreement between media specialists' observations and students' self-perceptions that many new graduates did not have a solid understanding of IL concepts and skills. One of the most surprising (and dismaying) finding of this study was that $39 \%$ of the surveyed students said that the survey question/explanation was the first they had heard of Information Power Standards, Handy 5 or Big 6, all of which address competencies recognized for K-12 IL skills. It is possible that only the terms were new to them, but the students did not connect the terms with skills they had learned or were learning to teach. It was encouraging to see positive comments from some students that they were glad to have this information and that they would incorporate it into their teaching and learning in the future. While students answered that they are able for the most part to find and use information, there were not many of comments indicating that they saw a connection between doing task-based projects for college coursework and passing the required skills on to their own students. Emphasizing that connection is an area where academic librarians can provide added value beyond basic instruction to education students.

Responses by students as to the priority for teaching IL skills and how they would accomplish it are quite positive. These responses contrast sharply with the observations and perceptions of the media specialists. (Figure 2). While it must be taken into account that the idealism often seen in students tends to become much more pragmatic as they enter the working world, it is hoped that librarians and teaching faculty can work together to foster the importance of maintaining this priority. 
Figure 2. Comparison of Student Predictions about Teaching IL Skills in Future Classrooms and Media Specialists' Reported Observations of Teachers' Behavior

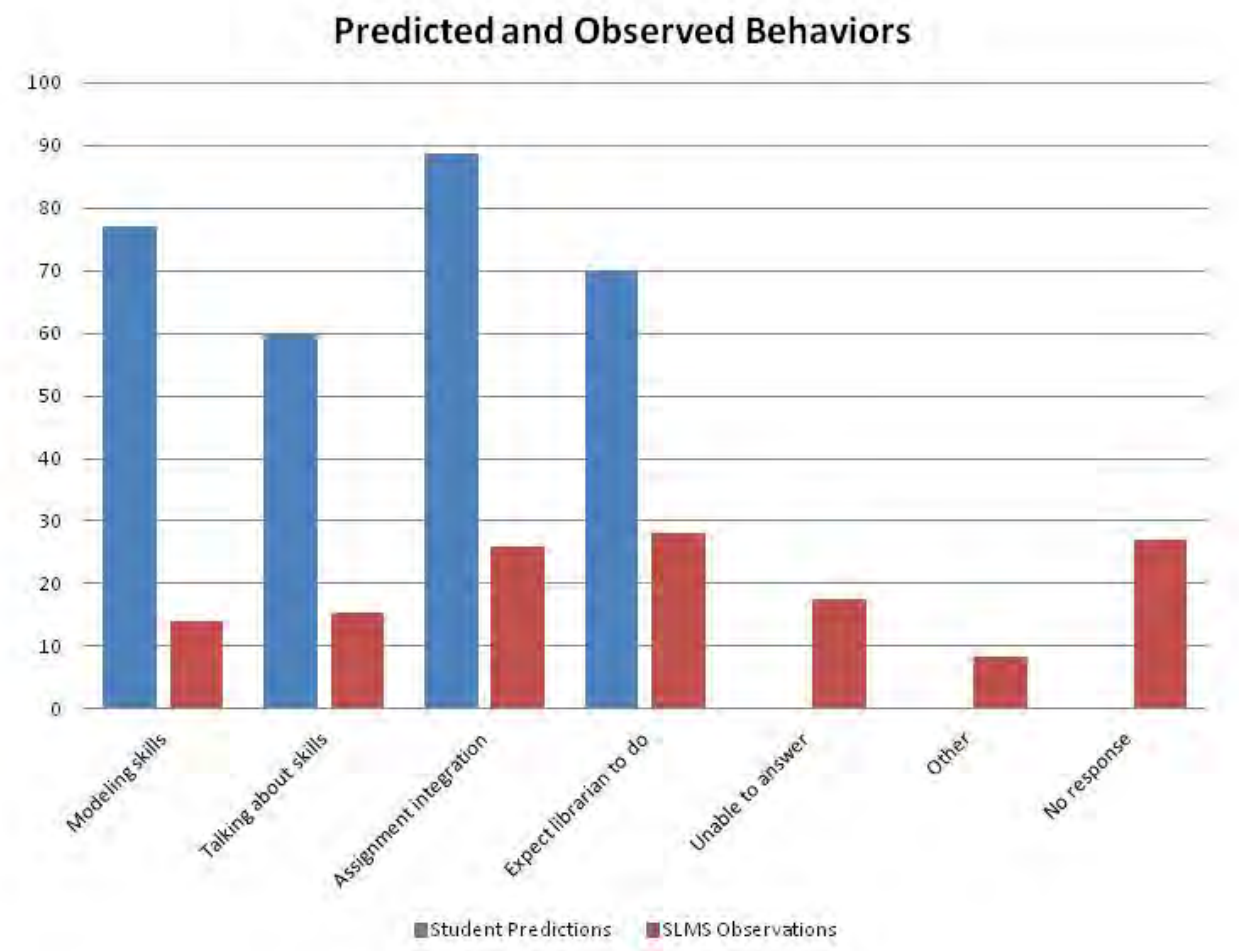

\section{Conclusion}

It is clear that there is room for improvement in the area of IL for education majors at these two universities, especially as they move beyond their college years to become professional teachers. The authors believe that this survey exposed students to terms and concepts they may not have been familiar with, and encouraged them to think about the importance of the concepts. In addition, by the time they answered the last question, most student respondents seemed to grasp the idea that they could seek help from librarians. A second student survey with a larger sample population is desirable not only to validate these preliminary data, but also to afford teachable moments about and continue exposure to the concepts of IL. Locally, results of this study can demonstrate to the education faculty at the two campuses the importance of incorporating IL skills into the curriculum and potential collaboration with education librarians. The authors used this information immediately to incorporate some changes to class instruction. For example, while teaching specific IL skills during library instruction classes, they also emphasized how learning skills as a university student now can be used to help their own students later. The importance of knowing the school librarian and using collaboration opportunities once they become professional teachers was also stressed. The perspectives of the school media specialists provide opportunities to continue conversations about better partnerships between academic librarians and school librarians, with a common goal of helping young students as well as university students develop skills to become lifelong learners and productive citizens.

\section{References}

American Association of School Librarians \& Association for Educational Communications and Technology. (1998). Information literacy standards for student learning. Retrieved from 
http://www.ala.org/ala/mgrps/divs/aasl/aaslarchive/pubsarchive/informationpower/InformationLiteracyS tandards_final.pdf

Asselin, M. M., \& Lee, E. A. (2002). "I wish someone had taught me": Information literacy in a teacher education program. Teacher Librarian, 30(2), 10-17.

Blume, S., Fox, C., Lakin, J. M., Losey, B., \& Stover, J. (2007). The handy 5: Planning and assessing integrated information skills instruction $\left(2^{\text {nd }}\right.$ ed.). Scarecrow Press. Available from http://www.scarecrowpress.com

Bushong, S., \& Buff, C. (2008). Information literacy for teaching and learning: A course for teacher practitioners. Education Libraries, 31(2), 12-18.

Dow, M. (2011). Emporia State University school of library \& information management. Retrieved from http://slim.emporia.edu/index.php/dr-mirah-dow-3/

Dow, M. (2010). Making schools better: School librarians' roles in aggressive reforms: What is our official position? Knowledge Quest, 38(5), 78-82.

Earp, V. (2009). Integrating information literacy into teacher education: A successful grant project. Behavioral \& Social Sciences Librarian, 28(4), 166-178.

EBSS Instruction for Educators Committee. (2011). Information literacy standards for teacher education. Retrieved from http://www.ala.org/ala/mgrps/divs/acrl/standards/ilstandards_te.pdf

Educational Testing Service. (2011). Reintroducing the iSkills assessment from ETS. Retrieved from http://www.ets.org/iskills/about

Eisenberg, M. (2001, November 19). Big6 skills overview. Retrieved from http:/www.big6.com/2001/11/19/a-big6\%E2\%84\%A2-skills-overview/

Floyd, D. M., Colvin, G., \& Dodur, Y. (2008). A faculty-librarian collaboration for developing information literacy skills among preservice teachers. Teaching and Teacher Education, 24(2), 368-376.

Foster, A. L. (2006). Students fall short on 'information literacy,' educational testing service's study finds. Chronicle of Higher Education, 53(10), A36-A36.

Gross, M., \& Latham, D. (2009). Undergraduate perceptions of information literacy: Defining, attaining, and self-assessing skills. College \& Research Libraries, 70(4), 336-350.

Kansas State University Libraries mission statement. (2011). Retrieved from http://www.lib.kstate.edu/geninfo/plan/

Latham, D., \& Gross, M. (2008). Broken links: Undergraduates look back on their experiences with information literacy in K12 education. School Library Media Research, 11.

Laverty, C., \& Reed, B. (2006). In D. Cook, \& N. Cooper (Eds.), Teaching information literacy skills to social sciences students and practitioners: A casebook of applications (pp. 68-83). Chicago: Association of College and Research Libraries.

Moore, P. (2002). An analysis of information literacy education worldwide. Retrieved from http://portal.unesco.org/ci/en/files/19633/11228857221Information_Literacy_Education_\%28Moore\%2 9.pdf/Information\%2BLiteracy\%2BEducation\%2B\%28Moore\%29.pdf

The Association of College and Research Libraries, a Division of the American Library Association. (2000). Information literacy competency standards for higher education. Retrieved from http://www.acrl.org/ ala/mgrps/divs/acrl/standards/standards.pdf

Washburn University Libraries mission statement. (2011). Retrieved from http://www.washburn.edu/mabee/strategic_plan/index.shtml 


\section{Appendix A.}

\section{Survey for Media Specialists/School Librarians}

\section{Introduction:}

With emphasis on information literacy in higher education, academic librarians strive to impart these skills to college students, including education majors. To assess this work, it would help us greatly to learn your perceptions as a media specialist familiar with these concepts. This is not a measurement of new teachers' skills, but rather an overview of the landscape of information literacy in the field of education, and how we as librarians can improve it.

Analysis of these survey results may be presented at future library conferences or in library-related publications, but there will be nothing that ties your identity to specific results and your name will not be associated in any way with the research findings. This survey is solicited, anonymous and completely voluntary and your input is very important to us. You should be aware that even if you agree to participate you are free to withdraw at any time, without penalty. It should take you approximately 5-10 minutes to complete and submit the survey. You may skip any questions that you are not comfortable answering. Thank you for your help!

\section{Questions:}

Do you have any recent graduates entering the teaching profession (less than 3 years) in your school? If no, survey ends here, participants are thanked for their time.

If yes, participants are allowed to continue to the next question.

We realize that not every new college graduate is the same. Please share your observations of most (or the average) new teacher in your school.

1. In your opinion, what level of understanding of information literacy (Information Power Standards) concepts and skills do most new graduates demonstrate?
a. Demonstrate clear understanding
b. Demonstrate low understanding
c. Have no awareness
d. I don't know

\section{Comments}

2. In the classroom, have you observed new graduates demonstrate the awareness of these skills by? (check all that apply)
a. Modeling Information Literacy Standards to students
b. Talking about Information Literacy Standards to students
c. Integrating standards into assignments / rubrics
d. Bringing students to the media center with expectations of learning these skills
e. Not able to answer

\section{Comments}

3. Describe any collaboration or relationship you have with new graduates on Information Literacy concepts and skills

a. They collaborate frequently with me to teach information literacy skills

b. They mostly expect me to teach these skills

c. They prefer to teach these skills without me

d. They are aware of concepts and skills, but I have not seen them incorporate them into routine work. 
e. I find that I have needed to educate/inform them of methods and importance for teaching these skills.

Comments

4. In your opinion, do these new graduates know where and how to find needed reference or professional materials (are they information literate?)

a. Yes, they have a good idea of where to find appropriate materials

b. They have some idea of where to find appropriate materials

c. No, they don't seem to know where to find appropriate materials, but depend on me for help.

d. I don't know whether they are finding needed and appropriate materials.

Comments

5. In your opinion, do new education graduates have a solid understanding of Information Literacy (Information Power Standards) skills and concepts?

a. Yes

b. No

Comments

6. What Information Literacy concept or skill do you feel should be stressed more to college education majors?

Comments

\section{Survey for undergraduate Education Majors Introduction:}

We would like your help. As academic librarians, our goal is to help college students learn about accessing, evaluating and using needed information. As future teachers, it would help us greatly to learn your perceptions of these concepts. This is not a measurement of your skills, but rather an overview of the landscape of information literacy in the field of education, and how we as librarians can improve it. Analysis of these survey results may be presented at future library conferences or in library-related publications, but there will be nothing that ties your identity to specific results and your name will not be associated in any way with the research findings. This survey is solicited, anonymous and completely voluntary and your input is very important to us. You should be aware that even if you agree to participate you are free to withdraw at any time, without penalty. It should take you approximately 5-10 minutes to complete and submit the survey. You may skip any questions that you are not comfortable answering. Thank you for your help!

\section{Questions:}

In researching materials for my college class papers or projects, I access, evaluate, and use the information in an appropriate way.

1. I know how to find the needed information

Frequently

Occasionally

Rarely

2. If I don't know where to look, I know to ask a librarian or my instructor

Frequently

Occasionally

Rarely 
3. I carefully evaluate the information I find to determine whether it is accurate, believable, appropriate for my use.

Frequently

Occasionally

Rarely

4. I use the information ethically by knowing how to appropriately cite references

Frequently

Occasionally

Comments

Rarely

Information Literacy Competencies for K-12 students (also called Information Power Standards, Handy 5, Big 6, etc.) include concepts such as: knowing how to access, evaluate and use information in order to become independent learners that allow them to become socially responsible.

5. Are you familiar with these concepts?

a. Very familiar with these concepts

b. Somewhat familiar with these concepts

c. I've heard of these concepts

d. This is the first I've heard of these concepts

Comments

6. Have you constructed a lesson plan or thematic unit that teaches any of these skills (knowing how to access, evaluate, and use information...) to the students?
a. Yes
b. No

Comments

7. If you answered yes to question 6 , would you share an example you used?

If you answered no to question 6 , would you tell us why not?

8. As a teacher, would you see the teaching of these skills and concepts as a priority in your regular classroom work?
a. Yes, high priority
b. Yes, priority
c. Low priority
d. Not a priority

Comments

9. As a teacher, which of the following would you use personally? (check all that apply)

a. Modeling Information Literacy Standards to students

b. Talking about Information Literacy Standards to students

c. Integrating standards into assignments / rubrics

d. Bringing students to the media center with expectations of learning these skills from the media specialist

e. None of these

Comments 
Thinking about the previous questions and whether you would incorporate some method of Information Literacy into your future classrooms:

10. Where would you seek help or resources to teach these concepts?

Comments

\section{Marcia Stockham}

Assistant Dean for Content Management and Scholarly Communication

(Former Education Librarian)

504 Hale Library,

Kansas State University

Manhattan, KS. 66506

stockham@,ksu.edu

\section{Heather Collins}

Biomedical Librarian

(Former Education Librarian at Washburn University)

A.R. Dykes Health Sciences Library

University of Kansas Medical Center

3901 Rainbow Boulevard

Kansas City, KS 66160

hcollins@,kumc.edu 